\title{
Implementasi Pembelajaran Penjas Di SDN-4 Kota Palangka Raya
}

\author{
Cukei, Chandra Audina Mulya, Jaka Raksa \\ Jurusan Pendidikan Jasmani Kesehatan dan Rekreasi, Fakultas Keguruan Dan \\ Ilmu Pendidikan, Universitas Palangka Raya, Indonesia \\ Email : cukei1120@gmail.com
}

\begin{abstract}
Abstrak. Permasalahan dalam penelitian ini adalah para guru di sekolah dasar perlu mendapat bekal pengetahuan, khusus agar dalam menangani anak didiknya yang selalu berpegang pada nilai - nilai ilmu pengetahuan yang berhubungan dengan pemecahan masalah dalam kegiatan pembelajaran Penjas, guru sebagai komponen utama dalam proses belajar mengajar sangat menentukan untuk tercapainya tujuan belajar yang diinginkan. Tujuan penelitian ini adalah ingin menetahui pelaksanaan pembelajaran Penjas SDN-4 Kota Palangka Raya. Untuk memperoleh kebenaran tujuan dalam penelitian ini diperlakukan metode yang tepat, mengingat penelitian ini tidak berhipotesis, serta hanya mengungkapkan apa adanya tentang sesuatu variabel, maka jenis penelitian ini adalah penelitian kualitatif, subjek yang digunakan dalam penelitian ini adalah SDN-4 Kota Palangka Raya. Instrumen penelitian yang dipergunakan dalam penelitian ini adalah disesuaikan dengan tujuan penelitian, dilakukan melalui wawancara dan observasi terhadap responden penelitian. Hasil penelitian menunjukan bahwa ditempat penelitian ini telah di implementasikan dan diatasi tentang pelaksanaan pembelajaran Penjas yaitu perencanaan, organisasi, pengelolaan pembelajaran penjas, perangkat dan pendekatan pembelajaran Penjas, kendala yang dihadapi dan solusi dalam mengatasi sumber belajar dan penilaian pembelajaran penjas, di SDN-4 Kota Palangka Raya.
\end{abstract}

Kata Kunci : Implementasi, Pembelajaran, Penjas

\section{PENDAHULUAN}

Salah satu aspek yang dapat menumbuhkan intelegesi salah satunya peranan cabang olahraga pada pendidikan Jasmani kesehatan dan olahraga merupakan salah satu alat dalam pembangunan bangsa, khususnya dalam bidang Jasmani dan rokhani. Untuk mencapai hasil pembangunan yang baik perlu adanya peningkatan sumber daya manusia.

Pada hakekatnya didalam pembelajaran Penjas adalah kegiatan jasmani yang dilandasi semangat perjuangan melawan diri pribadi, alam lingkungan, dan orang lain serta apabila dipertandingkan harus dilakukan dengan cara kesatria. Sehingga pendidikan jasmani merupakan sarana pendidikan pribadi yang ampuh menuju peningkatan kualitas hidup yang lebih baik. Peranan pendidikan jasmani adalah bertujuan sebagai perwujudan masyarakat Indonesia yang berkualitas tidak diragukan lagi. Pembelajaran Penjas berperan dalam mewujudkan manusia Indonesia dan masyarakat yang berkualitas, yang memiliki kekuatan dan keunggulan daya saing serta dapat menjadi kebanggaan nasional bagi bangsa Indonesia di forum internasional.

Pembelajaran Penjas di sekolah telah disusun dalam suatu kurikulum yang disampaikan dengan tujuan pembelajaran cukup jelas tercantum dalam kurikulum pendidikan jasmani dan kesehatan yang berlaku. Sedangkan kegiatan Pendidikan Jasmani yang penekanannya adalah pada pemecahan masalah. 
Para guru di sekolah dasar maupun di sekolah lanjutan tingkat pertama perlu mendapat bekal pengetahuan khusus agar dalam menangani anak didiknya yang selalu berpegang pada nilai - nilai ilmu pengetahuan yang berhubungan dengan pemecahan masalah dalam kegiatan pembelajaran.

Guru sebagai komponen utama dalam proses belajar mengajar sangat menentukan untuk tercapainya tujuan belajar yang diinginkan. Akan tetapi penyampaian materi pelajaran yang dilakukan kadang-kadang masih belum sesuai dengan tuntutan kurikulum, dan penggunaan metode mengajar yang banyak bersipat komando dan masih belum berpusat pada murid sehingga rendahnya prestasi belajar siswa. Selain itu guru masih kurang memahami karakteristik siswa di lapangan. Di mana guru masih kurang bisa menciptakan iklim belajar mengajar yang menunjang kreativitas siswa. Keberadaan guru Penjaskes di sekolah masih belum memberikan nilai tambah yang diperlukan oleh siswa, jika disesuaikan dengan kebutuhan dan perkembangan jiwa dan raga siswa di sekolah.

Berdasarkan uraian diatas maka penulis tertarik untuk meneliti dengan Judul "Implementasi Pembelajaran Penjas di SDN-4 Kota Palangka Raya." Hasil penelitian ini diharapkan dapat memberikan kontribusi dalam pengembangan ilmu pengetahuan dalam pembelajaran Penjas SDN-4 Kota Palangka Raya. Bagi peserta didik, semoga penelitian ini dapat memberikan gambaran tentang pembelajaran yang menyenangkan sehingga anak dapat menemukan pengetahuan sendiri. Bagi pendidik khususnya, penelitian ini diharapkan mampu menjadi acuan dalam persiapan pembelajaran kearah yang lebih baik

Implementasi dan penerapan metode mengajar dalam pendidikan jasmani perlu disesuaikan dengan kondisi dan situasi belajar-mengajarnya. Dougherly dan Bonanno yang dikutip olehBrotosuryo(2014:25) mengemukakan pandangannya terhadap metode mengajar, sebagai berikut :

1. Tidak ada metode mengajar yang paling baik untuk selamanya, setiap metode mengajar memiliki kelebihan dan kekurangan pada gaya itu sendiri

2. Ada periode yang membuat atau menyebabkan berhenti dalam menggunakan salah satu metode mengajar.

3. Jangan ragu untuk mengkombinasi gaya-metode mengajar

4. Jangan terpaku atau terkunci pada mengajar tertentu. Pengulangan metode mengajar yang terus menerus tanpa mengabaikan perubahan-perubahan pelajaran pokok akan membuat siswa jemu.

\section{METODE PENELITIAN}

Rancangan penelitian yang digunakan dalam penelitian ini adalah menggunakan pendekatan kualitatif. Oleh karena itu penelitian kualitatif tidak menggunakan logika deduktif verifikatif, namun yang digunakan adalah logika induktif abstraktif seperti yang dikemukakan oleh Faisal (2002:6) bahwa penelitian kualitatif adalah suatu logika yang bertitik tolak dari "khusus ke umum", bukan dari "umum ke khusus sebagaimana dalam logika deduktif verifikatif. Fenomena di dalam penelitian kualitatif adalah kasus-kasus tertentu yang tidak bisa digeneralisasikan, karena bersifat memahami menurut sudut pandang, asumsi, definisi, ukuran, logika dari subyek penelitian itu sendiri.

Berdasarkan pemikiran yang dikemukakan di atas, maka rancangan penelitian dengan pendekatan kualitatif yang akan digunakan dalam penelitian ini menetapkan konstruksi desain deskriptif kualitatif meliputi : Pendahuluan terdiri 
dari : Judul penelitian, latar belakang masalah, rumusan masalah, tujuan penelitian, manfaat penelitian, dan kajian pustaka/teori yang akan digunakan. Metode Penelitian mencakup : subyek penelitian, lokasi penelitian, instrumen penelitian, sumber data, teknik pengumpulan data, prosedur pengolahan data, uji keabsahan data, paparan data, temuan penelitian dan pembahasan, serta laporan penelitian.

Penelitian ini menggunakan pendekatan kualitatif, maka kehadiran peneliti di lapangan adalah penting dan menentukan serta diperlukan secara optimal. Hal ini disebabkan karena peneliti bertindak sebagai instrumen utama (kunci) sekaligus sebagai pengumpul data penelitian. Sugiyono (2009:222) mengemukakan bahwa : "...dalam penelitian kualitatif, yang menjadi instrumen atau alat penelitian adalah peneliti itu sendiri. Oleh karena itu peneliti sebagai instrumen juga harus "divalidasi" seberapa jauh peneliti kualitatif siap melakukan penelitian yang selanjutnya terjun ke lapangan..."

Dengan demikian peneliti sebagai human instrumen, berfungsi menetapkan fokus penelitian, memilih informan sebagai sumber data, melakukan pengumpulan data, menilai kualitas data, analisis data, menafsirkan data dan membuat kesimpulan atas temuan penelitian. Dalam pengumpulan data penelitian dengan pendekatan kualitatif menggunakan beberapa teknik seperti : 1) teknik observasi, 2) teknik wawancara mendalam, 3) teknik studi dokomentasi dan 4) tringulasi.

Untuk proses analisis data dalam penelitian ini dilakukan sejak sebelum memasuki lapangan, selama di lapangan dan setelah selesai dari lapangan. Oleh karena itu, kegiatan analisis dan penarikan kesimpulan tidak hanya dilakukan pada tahap akhir penelitian, melainkan telah dimulai sejak awal pengumpulan data.

Kegiatan analisis data dilakukan sepanjang proses pengumpulan data berlangsung, dan setelah selesai pengumpulan data dalam waktu yang sudah ditentukan atau sesuai dengan tahapan penelitian. Juga pada saat wawancara, peneliti sudah melakukan analisis terhadap terhadap jawaban para informan yang menjadi subyek penelitian. Apabila jawaban yang para informan yang diwawancarai setelah dianalisis terasa belum memuaskan, maka peneliti akan melanjutkan pertanyaan lagi sampai diperoleh data yang dianggap kredibel. Cara ini peneliti lakukan untuk mengembangkan pelacakan dan penjelajahan lebih lanjut terhadap data yang diperlukan, sehingga dapat memperoleh data yang kredibel dalam mengungkapkan fenomena yang ada pada pembelajaran Penjas di SDN-4 Kota Palangka Raya.

Teknik analisis data yang peneliti gunakan dalam penelitian ini yaitu menggunakan model analisis interaktif yang mencakup empat komponen yang saling berkaitan yaitu : pengumpulan data, reduksi data, pemaparan data, dan penarikan kesimpulan dan verifikasi data. Oleh karena itu, proses analisis data dan penarikan kesimpulan tidak hanya dilakukan pada tahap akhir penelitian, melainkan telah dimulai sejak awal pengumpulan data

Di dalam uji keabsahan data pada penelitian kualitatif meliputi : Uji Kepercayaan (Credibility) . Untuk uji kepercayaan data ini peneliti melakukan langkah-langkah sebagai berikut :

1. Perpanjangan Pengamatan, dengan perpanjangan pengamatan peneliti berupaya agar dapat menyatu dengan informan atau nara sumber, karena 
dengan semakin akrap memungkinkan dapat menghilangkan keraguan atau tidak ada jarak lagi antara peneliti dengan informan

2. Triagulasi, data dari berbagai sumber dengan berbagai cara dan berbagai waktu. Jadi ada triangulasi sumber data, triangulasi teknik pengumpulan data, dan waktu.

3. Keteralihan (Transferability) menunjukkan derajat ketepatan atau diterapkannya hasil penelitian

4. Kebergantungan (Dependability) yaitu melakukan audit terhadap keseluruhan proses penelitian yang dilakukan oleh pembimbing untuk mengetahui apakah peneliti sudah melalui suatu proses dalam melaksanakan penelitian.

5. Kepastian (Confirmability) yaitu untuk mengetahui dan menguji hasil penelitian, bila hasil penelitian sudah melalui proses penelitian yang sebenarnya.

Sehubungan dengan uraian data yang berhubungan dengan judul penelitian yaitu Implementasi Pembelajaran Penjas di SDN-4 Kota Palangka Raya, adalah sebagai berikut :

1) Perencanaan Pembelajaran

2) Organisasi Pembelajaran

3) Pengelolaan pembelajaran

4) Kedala dan solosi dalam pembelajaran penjas

5) Mengatasi sumber belajar

6) Mengatasi Media Pembelajaran

7) Pendekatan Pembelajaran

8) Penilaian pembelajaran Penjas

9) Perangkat Pembelajaran

\section{HASIL DAN PEMBAHASAN Implementasi Pembelajaran}

Pada pembahasan tentang pelaksaan aktivitas belajar mengajar berpedoman pada persiapan pengajaran yang dibuat. Pemberian bahan pelajaran disesuaikan dengan urutan yang telah diprogram secara sistematis dalam tahap persiapan. Langkah-langkah Implementasi pembelajaran meliputi yaitu: kegiatan awal, kegiatan inti, dan kegiatan akhir. Kegiatan awal merupakan kegiatan awal tatap muka antara guru dan siswa. Dalam kegiatan ini guru memberi petunjuk, pengarahan dan appersepsi, atau dapat juga dengan menyampaikan tujuan yang akan dicapai dan memberikan beberapa pertanyaan (pretest). Dalam kegiatan inti, guru menjelaskan materi dengan menggunakan pendekatan, metode dan teknik yang seudah ditentukan. Sedangkan dalam kegiatan akhir dapat berupa umpan balik dan penilaian.

Dalam Implementasi program pembelajaran, guru lebih dahulu harus mengadakan pretest untuk mengetahui penguasaan siswa terhadap bahan pelajaran, kemudian pada akhir pelajaran, guru mengadakan postest sebagai akhir dari seluruh proses interaksi belajar mengajar. Dalam penyampaian bahan pelajaran, guru menggunakan metode dan fasilitas yang sesuai dengan bahan pelajaran yang diberikan kepada siswa. Penggunaan fasilitas untuk mengurangi verbalisme dan membantu siswa memahami pelajaran yang diberikan agar siswa mendapat penjelasan yang tepat dan benar, sehingga tujuan pembelajaran dapat 
dicapai secara efektif dan efisien. Kesalahan penggunaan metode dan fasilitas menyebabkan tujuan pembelajaran sukar dicapai.

Kedala dan solosi dalam pembelajaran Penjas jika musim hujan dan sarana pembelajaran masih bisa diatasi dengan belajar diruangan, dan sarana pembelajar yang belum ada disekolah maka guru berkreatifitas dalam pengadaan sarana dan prasarana olahraga.

Sebagai pembahasan tentang Sumber belajar (learning resources) adalah semua sumber baik berupa data, orang dan wujud tertentu yang dapat digunakan oleh peserta didik dalam belajar, baik secara terpisah maupun secara terkombinasi sehingga mempermudah peserta didik dalam mencapai tujuan belajar atau mencapai kompetensi tertentu. manfaat sumber belajar adalah Memberikan pengalaman belajar secara langsung dan konkret kepada pesert didik Dapat menyajikan sesuatu yang tidak mungkin diadakan, dikunjungi atau dilihat secara langsung dan konkret.

\section{KESIMPULAN}

Ada tiga kesimpulan yang bisa ditarik dari hasil penelitian ini sebagai berikut :

1). Perencanaan pembelajaran jangka panjang artinya sudah ada program yang sudah terstruktur maksudnya yaitu dari kurukulum, program tahunan, program semester, dan perhitungan hari efektif serta disesuaikan dengan kurikulum yang ada. Kemudian dikatakan bahwa adanya Program jangka menengah, sudah ada yaitu program semester, program tengah semester, rpp disesuaikan dengan kurikulum yang ada, Uts ulangan tengah semester, Di dalam organisasi terdapat suatu aktivitas pengorganisasian yang meliputi, Menggolong-golongkan tindakan yang harus dilakukan dalam kesatuan-kesatuan tertentu. Penyusunaan bentuk dan pola usaha kerjasama dalam pembelajaran atau kurikulum. Menentukan tugas bagi orang-orang yang tergabung dalam kegiatan pembelajaran.

Menentukan wewenang masing-masing peserta Menetapkan jalinan kerja di antara mereka, serta saluran perintah atau tanggung jawab. 1)pengelolaan saat melaksanakan pembelajaran Penjas dengan menggunakan pendekatan pembelajar saintifik, pada materi pelajaran yang akan diajarkan,pengelolaan pembelajaran, bahwa dalam pengelolaan program pembelajaran Penjas ada beberapa langkah atau tahapan yang harus dijalani oleh seorang guru. Tahapan tersebut sama dengan tahapan pengelolaan pembelajaran mata pelajaran antara lain, yaitu: "Tahap persiapan atau perencanaan, Implementasi, dan penilaian atau evaluasi".

2). Perangkat pembelajaran merupakan sejumlah bahan, alat, media, petunjuk dan pedoman yang akan diapakai dalam proses pembelajaran. Dari uraian tersebut bisa kita dikemukakan bahwa perangkat pembelajaran ialah sekumpulan media atau sarana yang dipakai oleh guru dan siswa dalam proses pembelajaran di kelas atau dilapangan olahraga. Contohnya sarana dan prasarana, kita manfaatkan sebaik mungkin seperti bola sepak bola voli, matreas kita manfaat sebaik nungkin kecuali kita tidak bisa praktek, oleh karena hujan sehinggsa kita tidak bisa manfaatkan seperti media pembelajaran sebagai alat bantu dalam proses belajar dan pembelajaran adalah suatu kenyataan yang tidak bisa kita pungkiri keberadaannya. 
3). Mengatasi kendala utama dalam pembelajatan Penjas adalah jika musim hujan, seharusnya mata pelajaran dilapangan maka bisa diajarkan diruangan saat sekarang akan tetapi kita masih bisa teori didalam ruangan pada saat hari yang baik kita bisa melaksanakan praktek, seperti senam ketangkasan bisa dilakukan didalam ruangan secara bergantian menggunakan matras. Masalah sarana dan prasarana yang tersedia di tempat penelitian ini kalau sarana parasarana yang ada disekolah seperti atletik sudah lengkap senam lengkap tenis meja kurang, oleh karena tenis meja, vola voli masih kurang akan tetapi bisa diatas dengan bola modifikasi.

\section{DAFTAR PUSTAKA}

Arikunto, Suharsini. (1990). Dasar - Dasar Pendidikan. Jakarta : Penerbit CV. Bumi Aksara.

Abdoellah, Arma. (1981). Olahraga untuk Perguruan Tinggi. Yogyakarta : Penerbit CV. Sastra Hudaya.

Nurhasan. (1990). Tes dan Pengukuran Olahraga. Fakultas Pendidikan Olahraga dan Kesehatan. IKIP : Bandung.

Pusat Ilmu Olahraga. (2002). Buku Pedoman tentang Kondisi Fisik Olahragawan. KONI Pusat : Jakarta.

Alfabeta.cet. Ke-2. (2013).Kamus Besar Bahasa Indonesia (KBBI)

AzarAsyat. (2002). Media Pembelajaran. Jakarta: PT. Raja grafindo Persada

Bungin, H.M. Burhan. (2008). Penelitian Kualitatif. Komonikasi, Ekonomi, Kebijakan Publik, dan Ilmu Sosial Lainnya. Prenada Media Group, Jakarta.

Faisal, Sanapiah. (1998). Pengumpulan dan Analisis Data Dalam Penelitian Kualitatif, Kumpulan Materi Metode Penelitian Kualitatif, PPS Universitas Negeri Malang.

Faisal Sanafiah. (2002). Format Penelitian Sosial Dasar dan Aplikasi. Jakarta, Rajawali Press. 